\title{
Effect of Plasticity on Liquefaction Susceptibility of Sand-Fines Mixtures
}

\section{Aminaton Marto ${ }^{\mathrm{a}}$, Choy Soon $\operatorname{Tan}^{\mathrm{b}^{*}}$, Ahmad Mahir Makhtar ${ }^{\mathrm{c}}$, Ung Shu Wen ${ }^{\mathrm{d}}$ and Lim Mei Yen ${ }^{\mathrm{e}}$}

\author{
${ }^{1}$ Faculty of Civil Engineering - Construction Research Alliance, Universiti Teknologi Malaysia, \\ 81310 UTM Johor Bahru, Johor, Malaysia. \\ a aminaton@utm.my , ${ }^{*}$ cstan8@live.utm.my , camahir@utm.my , 'swenu21@gmail.com , \\ Ilimmie_yen@yahoo.com
}

Keywords: cyclic triaxial test, plasticity index, clay fraction, activity.

\begin{abstract}
The usability of the clay fraction as one of the criteria in the assessment of liquefaction susceptibility is questionable since year 2001. The use of plasticity index to replace clay fraction as a controlling parameter in the criterion is proposed. This paper aims to compare the usability of different parameter in describing the cyclic behaviour of sand-fines mixtures with various plasticity characteristics. The sand-fines mixtures were reconstituted by mixing clean sand with two types of plastic fines at different percentages by weight, at a standardized ratio of $80 \%$ of clean sand with $20 \%$ of plastic fines. All soil samples were mixed using the dry tamping method to achieve a constant relative density of $20 \%$ throughout the specimen. The soil specimens are tested with stress controlled cyclic triaxial apparatus under consolidated undrained condition, with an effective confining pressure of $100 \mathrm{kPa}$. The soil specimens were considered liquefy when the value of pore pressure is equivalent to the initial cell pressure, resulting zeroes effective stress in soil specimen. The results showed that the liquefaction resistance of the sand-fines mixtures increased as the value of plasticity index increased. The plasticity index is a better indicator to describe the liquefaction susceptibility of sand-fines mixtures compare to clay content, plastic limit and activity.
\end{abstract}

\section{Introduction}

Chinese Criteria [1] is the best known liquefaction susceptibility criteria that established after the 1975 Haichang Earthquake and the 1976 Tangshan Earthquake. The soil is susceptible to liquefaction if the (1) fraction finer than $0.005 \mathrm{~mm} \leq 15 \%$; (2) liquid limit $\leq 35 \%$ and (3) natural water content $\geq 90 \%$ of liquid limit. The Chinese Criteria have been modified by several researchers to cope with the deviation caused by the characteristics of the presenting fines in some empirical evidences as summarised in Table 1. The evolution route of Modified Chinese Criteria was summarized in another companion paper [2]. Modified Chinese Criteria must be reviewed with a wider context, especially the clay fraction as one of the criteria has been questionable [3]. Researchers have now hypothesized that plasticity index may be an accurate indicator in substituting percentage of clay-size particle amount in characterizing liquefaction susceptibility.

Most of earlier laboratory based researches are in a great deal with the effects of fines content toward liquefaction susceptibility, and only a minority of them included the plasticity characteristics of fines in their analysis. Derakhshandi et al [5] performed strain-controlled cyclic triaxial tests and found that specimens with below $20 \%$ of plastic fines have higher tendency to be liquefy compare to clean sands due to its water trap ability. Ghahremani and Ghalandarzadeh [6] pointed out that liquefaction resistance is first decreases with additional plastic fines and would then increase when exceeding certain percentages of plastic fines by weight. However, this phenomenon is more related to the theory of threshold fines content as describe by Lade [7]. Seed [8] stated that the sand-fines mixtures with plasticity range less than 10 is liquefiable but Perlea [9] found that the range of plasticity index that susceptible to liquefaction is between the values of 4 to 14. Park and Kim [10] show that under constant fines percentages of $10 \%$, sand-fines mixtures are more liquefiable as plasticity index is increasing. 


\begin{tabular}{ccc} 
& \multicolumn{2}{c}{ Table 1 List of earthquake events [4] } \\
\hline Year & Earthquake & Characteristics of liquefied soils \\
\hline 1964 & Niigata & $70 \%$ fines and $10 \%$ clay fraction \\
1968 & Tokachi & $90 \%$ fines and $18 \%$ clay fraction \\
1971 & San Fernando & Silty sands \\
1976 & Tangshan & $20 \%$ clay fraction \\
1983 & Idaho & $70 \%$ fines and $20 \%$ clay fraction \\
1993 & Hokkaido & $48 \%$ fines and $18 \%$ clay fraction \\
1999 & ChiChi & Fines content as high as 36\% to 53\% \\
1999 & Adapazari & $70 \%$ fines with plasticity 0 to 25 \\
2009 & Olanche & Fines content as high as $15 \pm 8 \%$ \\
2010 & Christchurch & Grey fine silty sands \\
\hline
\end{tabular}

Due to the discrepancy of the various comparison basis used by previous researchers, the investigations on the effect of plasticity characteristics with respect to liquefaction resistance are with contradicting statement. Hence, this study aims to compare the usability of different parameter in describing the cyclic behaviour of sand-fines mixtures with various plasticity characteristics.

\section{Laboratory Testing}

The clean sand used to form the sand-fines mixtures in this study is the natural sand obtained from a river in Johor Bahru, Malaysia. The clean sand is uniform medium sand (SP) with specific gravity of 2.63. The sand has sub-angular shape with light brown in colour. Two types of commercially available plastic fines used are (i) the low plastic fines (white kaolin) manufactured by Kaolin (Malaysia) Sdn Bhd and (ii) the highly plastic fines (green bentonite) manufactured by Harliburton (Malaysia) Sdn Bhd. In order to quantify the effect of plasticity on liquefaction susceptibility of sand-fines mixtures, cyclic triaxial test under consolidated undrained conditions were conducted on cylindrical size soil samples with approximately $100 \mathrm{~mm}$ height and $50 \mathrm{~mm}$ diameter. Five types of sand-fines specimens and the clean sand as the controlling sample were reconstituted using the dry tamping method to achieve a constant density index of $20 \%$. The density index of $20 \%$ represent loose state soil, which very vulnerable to liquation. The sand-fines mixtures were mixed by adding two types of plastic fines at five different ratios to the parent sand at a standardized ratio of $80 \%$ of clean sand and $20 \%$ of plastic fines by weight. Thevayanagam and Martin [11] explained that the addition of fines particles wills primarily infill the intergranular voids between sand grains and then secondly to form metastable grain contacts which will loosen the sand skeleton. The transition behavior from sand dominant to fine dominant is known as threshold fines content $\left(f_{\text {th }}\right)$, which normally is located within $20 \%$ to $40 \%$ of fines content. Therefore, this ratio was chosen because most of the soil samples having their threshold fines content $\left(f_{\text {th }}\right)$ at $20 \%$ of fines by weight, except sand-kaolin mixtures as shown in Fig. 1. The physical properties of altogether six types of specimens are presented in Table 2 while the particle size distribution for the sand-fines mixtures is shown in Fig. 2.

Prior to saturation process, carbon dioxide gases and de-aired water was circulated through the specimens from the bottom drainage line to the top. The saturation was carried out by applying suitable back pressure to a minimum Skempton B-value of 0.95 was obtained. After the saturation process was completed, the specimens were isotropically consolidated to back pressure of $200 \mathrm{kPa}$, with an initial effective pressure of $100 \mathrm{kPa}$ prior cyclic loading. The cyclic loading was imposed in the form of the sine waveform with a frequency of $0.5 \mathrm{~Hz}$ and amplitude of $0.1 \mathrm{kN}$. The soil specimens were considered liquefy when the value of pore pressure is equivalent to the initial cell pressure, resulting zeroes effective stress in soil specimen. 


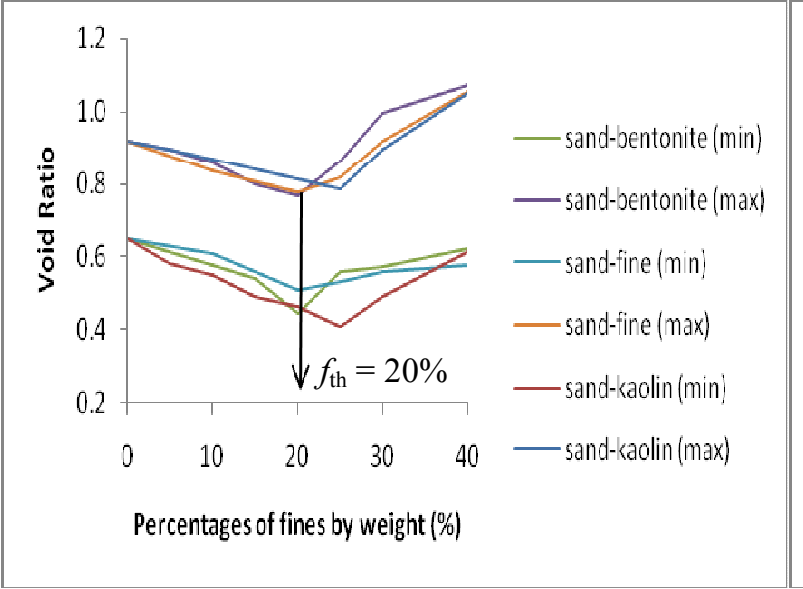

Fig. 1 Threshold fines content

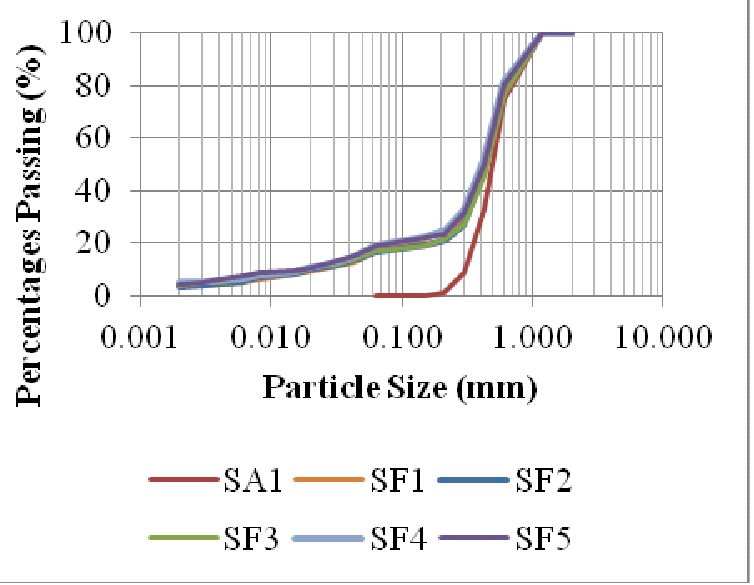

Fig. 2 Particle size distribution

Table 2 Physical properties of sand matrix soils

\begin{tabular}{ccccccccccc}
\hline Test & \multicolumn{3}{c}{ Material composition (\%) } & \multicolumn{3}{c}{ Soil composition (\%) } & \multicolumn{3}{c}{ Limits (\%) } & Colloidal \\
\cline { 2 - 8 } Series & Sand & Kaolin & Bentonite & Sand & Silt & Clay & $W_{\mathrm{L}}$ & $W_{\mathrm{P}}$ & $\mathrm{I}_{\mathrm{P}}$ & Activity (A) \\
\hline SA1 & 100 & 0 & 0 & 100 & 0 & 0 & 0 & 0 & 0 & 0 \\
SF1 & 80 & 20 & 0 & 83 & 13 & 4 & 39 & 26 & 13 & 1.00 \\
SF2 & 80 & 15 & 5 & 83 & 14 & 4 & 81 & 37 & 44 & 2.33 \\
SF3 & 80 & 10 & 10 & 82 & 14 & 5 & 162 & 44 & 118 & 4.55 \\
SF4 & 80 & 5 & 15 & 81 & 15 & 5 & 232 & 52 & 180 & 5.46 \\
SF5 & 80 & 0 & 20 & 80 & 16 & 5 & 294 & 59 & 235 & 6.12 \\
\hline
\end{tabular}

\section{Results and Discussion}

The typical test results of undrained cyclic triaxial loading tests were plotted in Fig. 3, particularly the deviator stress and the pore pressure development of clean sand specimen until the initiation of liquefaction. The liquefaction is defined when the value of pore pressure is equivalent to the initial cell pressure, resulting zero effective stress in soil specimen. Generally, additional of plastic materials in the matrix of sand may produce two opposite behaviours: (1) reduce permeability and hence increase the rate of pore pressure build up or (2) development of more cohesive character, thereby increase the liquefaction resistance. In overall, the results of this study show that when the plastic behaviour of the sand-fines mixtures is increasing, the number of cycles required to initiate the liquefaction is also increased. The sand-fines mixtures are more resistant to liquefaction susceptibility if it is more cohesive.

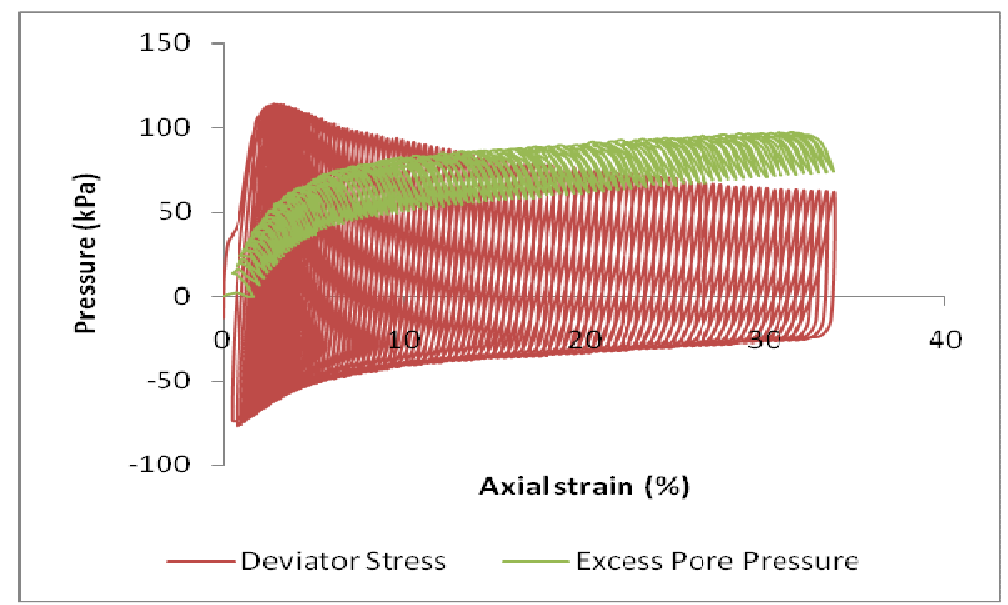

Fig. 3 Typical data for cyclic triaxial test 
The researchers hypothesised that plasticity index may be a more accurate indicator in substituting clay fraction in characterising the liquefaction susceptibility of sand matrix soils. However, the only drawback is the plasticity index of the sand matrix soils would be same regardless the presenting fines within the matrix of sand grain is either $10 \%$ or $50 \%$ by weight. The colloidal activity that defines as the ratio of plasticity index to clay fraction might solve this discrepancy. Therefore, Fig. 4 shows the number of cycles required to initiate the soil liquefaction for sand-fines mixtures with various comparison basis, including clay fraction, plastic limit, plasticity index and activity. By comparing the value of the coefficient of determination $\left(\mathrm{R}^{2}\right)$, the usability of different parameters in describing the liquefaction susceptibility of sand-fines mixtures with respect to plasticity characteristics could be observed. Based on the results, it shows that the value of $\mathrm{R}^{2}$ for plasticity index is the highest while the clay content has the lowest value. This proves that the hypothesis to substitute clay content with plasticity index in describing the effect of plasticity on liquefaction susceptibility of sand-fines mixtures is correct.

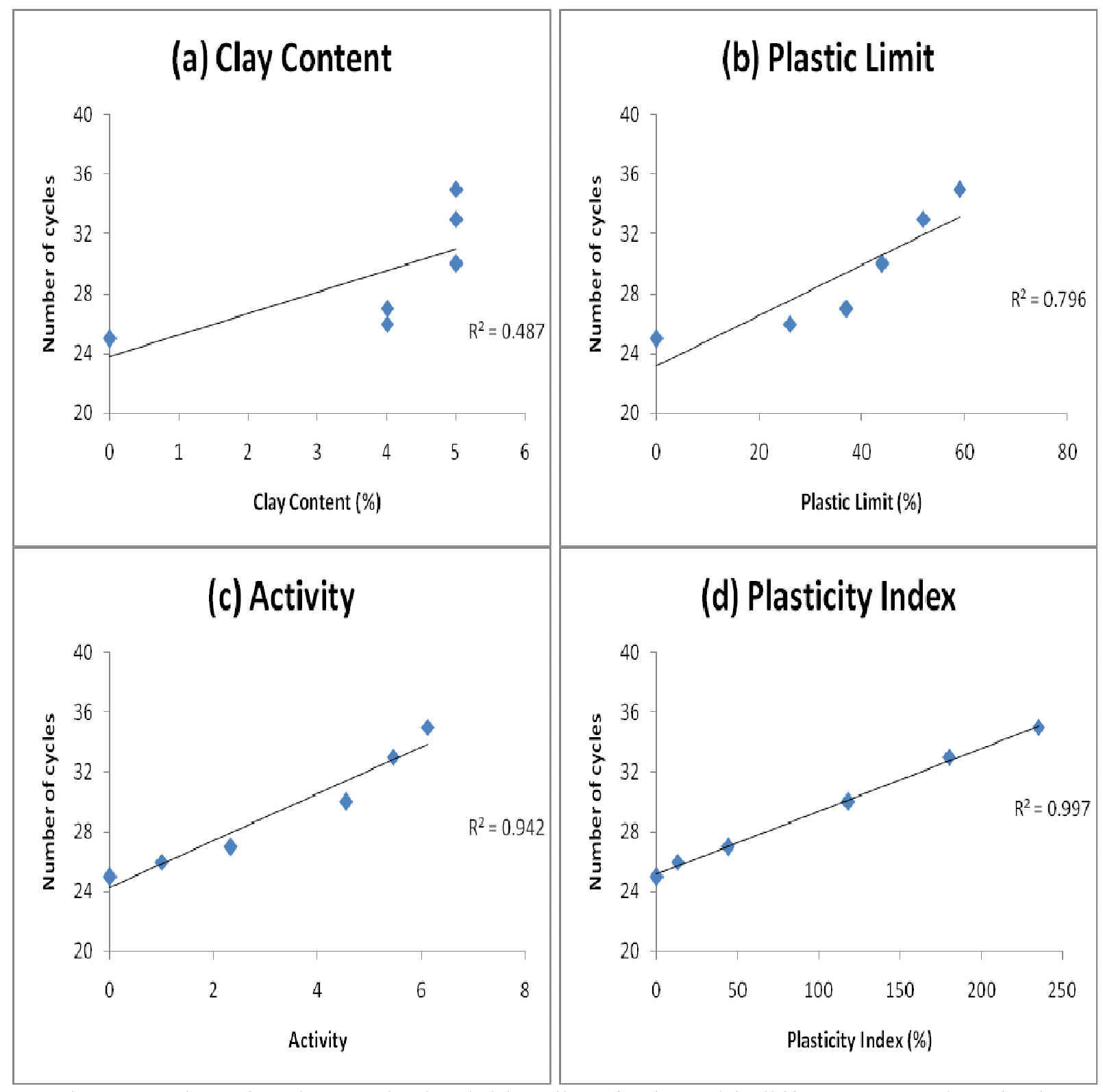

Fig. 4 Number of cycles required to initiate liquefaction with different comparison basis 


\section{Conclusion}

Based on the results of cyclic triaxial test under consolidated undrained condition, it can be concluded that the liquefaction resistance of the sand-fines mixtures increased as the value of plasticity behaviour increased. The plasticity index is a better indicator to describe the liquefaction susceptibility of sand-fines mixtures compare to clay content, plastic limit and activity.

\section{Acknowledgements}

The authors gratefully acknowledged the financial supports by the Ministry of Education (MOE) under the Fundamental Research Grant Scheme (Vot 4F316) and also the Universiti Teknologi Malaysia (UTM) through Zamalah program in undertaking the research to publish the results. The support of the Construction Research Centre and Construction Research Alliance, UTM is also acknowledged.

\section{References}

[1] W. Wang: Some findings in soil liquefaction, Report Water Conservancy and Hydroelectric Power Scientific Research Institute, Beijing, China. (1979) 1-17.

[2] A. Marto, C.S. Tan: Short Review on liquefaction susceptibility, International Journal of Engineering Research and Application, 2(3), (2012), 2115-2119.

[3] S. Prakash, V.K. Puri: Recent advances in liquefaction of fine grained soils, Proceddings of fifth international conference on recent advances in geotechnical earthquake engineering and soil dynamics San Diego, USA, (2010).

[4] A. Marto, C.S. Tan, K.L. Tiong, L.S. Teng: The roles of fines in liquefaction susceptibility of sand matrix soils, Electronic Journal of Geotechnical Engineering, 18 L, (2013), 2355-2368.

[5] M. Derakhshandi, E.M. Rathje, K. Hazirbaba, S. M. Mirhosseini: The effect of plastic fines on the pore pressure generation characteristics of saturated sands, Soil Dynamics and Earthquake Engineering, 28(5), (2008), 376-386.

[6] M. Ghahremani, A. Ghalandarzadeh: Effect of plastic fines on cyclic resistance of sands, Geotechnical Special Publication, 150, (2006).

[7] P.V. Lade, Reply to the discussion by Jefferies, Been, and Olivera: Evaluation of static liquefaction potential of silty sand slopes", Canadian Geotechnical Journal, 49(6), (2012) 751-752.

[8] R.B. Seed, K.O. Cetin, R.E. Moss, A.M. Kammerer, J. Wu, J.M. Pestana, A. Faris: Recent advances in soil liquefaction engineering: a unified and consistent framework, In Proceedings of the 26th Annual ASCE Los Angeles Geotechnical Spring Seminar: Long Beach, CA, (2003).

[9] V.G. Perlea, Liquefaction of Cohesive Soils, Soil Dynamics and Liquefaction, (2000) 58-76.

[10] S.S. Park, Y.S. Kim: Liquefaction resistance of sands containing plastic fines with different plasticity, Journal of Geotechnical and Geoenvironmental Engineering, (2012).

[11] S. Thevanayagam, G.R. Martin: Liquefaction in silty soils — screening and remediation issues, Soil Dynamics and Earthquake Engineering, 22, (2002) 1035-1042. 